мають гнучкість в оперуванні інформацією полікультурного змісту, впевненіше керуються принципами педагогічного такту під час спілкування з учнями та їхніми батьками представниками різних національностей, комфортніше себе почувають у багатокультурному учнівському середовищі під час нестандартних форм педагогічної роботи.

Отже, формування творчої особистості педагога $\epsilon$ потребою часу та відповідає вимогам компетентнісного підходу в освіті. Становлення творчої особистості майбутнього вчителя початкових класів в умовах полікультурного суспільства передбачає формування у студента етнопедагогічної творчості. Етнопедагогічна творчість як елемент і показник етнопедагогічної компетентності вчителя початкових класів передбачає здатність фахівця застосовувати здобутки етнопедагогіки задля створення творчого самопочуття, організації діалогічного педагогічного спілкування, удосконалення навчально-виховного процесу, зокрема й із метою формування творчої особистості дитини, створення нових технологій, систем навчання і виховання тощо.

Перспективами вивчення проблеми є розгляд питань удосконалення етнопедагогічної творчості майбутніх фахівців у галузі початкової освіти у процесі формування в них інших видів педагогічної компетентності.

\title{
Література
}

1. Етнонаціональна структура українського суспільства: [довідник] / Свтух В.Б., Трощинський В. Г., Галушко К. Ю., Чернова К. О. - Київ : Наукова думка, 2004. - 342 с. 2. Зязюн І. А. Педагогіка добра: ідеали і реалії / Іван Андрійович Зязюн. - Київ : МАУП, 2000. - 312 с. 3. Маркова А. К. Психологический анализ профессиональной компетентности учителя / А. К. Маркова // Советская педагогика. - 1990. - №8. - С.82 - 88. 4. Педагогічна майстерність: [навч. посіб.] / [І. А. Зязюн, Л. В. Крамущенко, І. Ф. Кривонос та ін.]; за ред. І. А. Зязюна. - Київ : Вища школа, 2004. - 422 с.

УДК 372.47:510.5

Олександра Шаран, Володимир Шаран

\section{ВИКОРИСТАННЯ АЛГОРИТМІЧНОГО ПІДХОДУ У ПРОЦЕСІ ВИВЧЕННЯ КУРСУ «ТЕОРІЯ ТА МЕТОДИКА ФОРМУВАННЯ ЕЛЕМЕНТАРНИХ МАТЕМАТИЧНИХ УЯВЛЕНЬ»}

Шаран О. В., Шаран В. Л. Використання алгоритмічного підходу у процесі вивчення курсу «Теорія та методика формування елементарних математичних уявлень».

У статті розглянуто суть алгоритмічного підходу, описано технологію його використання на заняттях 3 «Теорії та методики формування елементарних математичних уявлень». Автори наголошують, що алгоритмізація сприяє формуванню професійних навичок та може бути засобом навчання творчого мислення студентів - майбутніх фахівців дошкільної освіти.

Ключові слова: алгоритмічний підхід, алгоритми, мислення, навчальний процес, студенти, математичні уявлення, дошкільна освіта.

Шаран А. В., Шаран В. Л. Использование алгоритмического подхода в процессе изучения курса «Теория и методика формирования элементарных математических представлений».

В статье рассмотрена суть алгоритмического подхода, описана технология его использования на занятиях по «Теории и методика формирования элементарных 
математических представлений». Авторы отмечают, что алгоритмизация способствует формированию профессиональных навыков и может быть средством обучения творческого мышления студентов - будущих специалистов дошкольного образования.

Ключевые слова: алгоритмический подход, алгоритмы, мышление, учебный процесс, студенты, математические представления, дошкольное образование.

Sharan O. V., Sharan V. L. The usage of algorithmic approach in the process of study the course «The theory and methodology of formation of elementary mathematical ideas».

The article examines the essence of algorithmic approach and the technology of its usage in the classes of «The theory and methodology of formation of elementary mathematical ideas». The authors emphasize that the algorithmisation promotes the formation of professional skills and it can be used as a means of students' creative thinking training - future specialists of preschool education.

Key words: algorithmic approach, algorithms, thinking, educational process, students, mathematical ideas, preschool education.

У Законі України «Про освіту» зазначається, що метою освіти є всебічний розвиток людини як особистості та найвищої цінності суспільства, розвиток іiі талантів, розумових і фізичних здібностей, виховання високих моральних якостей, формування громадян, здатних до свідомого суспільного вибору, збагачення на цій основі інтелектуального, творчого, культурного потенціалу народу, підвищення освітнього рівня народу, забезпечення народного господарства кваліфікованими фахівцями [3]. Одним із завдань сучасної вищої школи є перетворення навчання на своєрідний технологічний процес 3 гарантованим результатом. Ми згодні з В. Беспалько [1] в тому, що важливим напрямком сучасної педагогічної технології є розв'язання дидактичних проблем на шляху управління навчальним процесом із визначеними цілями, шляхи досягнення яких чітко окреслюються i характеризуються. В основу такого підходу покладена алгоритмізація процесу засвоєння нових знань, формування нових умінь і навичок.

Проблема використання алгоритмічного підходу в навчальному процесі не нова. Першим визначив алгоритмізацію як педагогічний підхід Лев Наумович Ланда. У 50-і і 60-і роки минулого століття ним досліджувалися теоретичні основи навчання учнів алгоритмів [4]. Становлення і розвиток алгоритмічного підходу в навчанні значною мірою забезпечили результати досліджень видатних психологів (П. Гальперіна, О. Леонтьєва, Н. Менчинської, Н. Тализіної та ін.) та дидактів (Ю. Бабанського, Л. Занкова, І. Лернера, М. Скаткіна, А. Усової та ін.). Науковці-методисти (В. Болтянський, В. Монахов, А. Столяр, І. Тесленко, С. Шварцбурд, М. Шкіль та ін.) велику увагу приділяли розробленню методики застосування алгоритмів у навчальному процесі. Проблеми, пов'язані 3 формуванням алгоритмічної культури з використанням нових інформаційних технологій, досліджували спеціалісти 3 інформатики й обчислювальної техніки та програмування (В. Глушков, А. Сршов, М. Жалдак, Ю. Первин, С. Шапіро та ін.).

Mema cmammi: розглянути можливості використання алгоритмічного підходу у процесі вивчення курсу «Теорія та методика формування елементарних математичних уявлень».

Алгоритм (від лат. Algorithmi за арабським ім'ям математика Аль-Хорезмі) - набір інструкцій (вказівок), які описують порядок дій виконавця для досягнення результату розв'язання завдання за скінченну кількість кроків. Важливими властивостями алгоритму є: 
зрозумілість для виконавця, дискретність (роздільність) та визначеність команд, результативність, масовість. Поняття «алгоритм» у педагогіці вищої школи включає зміст діяльності студентів в умовах її виконання чи в умовах майбутньої професійної діяльності.

Основні компоненти алгоритмічного мислення: структурний аналіз завдання, поділ великого завдання на малі, зведення нерозв'язаного завдання до раніше розв'язаних, планування можливих ситуацій і реакцій на них, розуміння й використання формальних способів запису розв'язання - носять універсальний характер і мають застосування практично у всіх сферах людської діяльності.

На заняттях $з$ методики формування елементарних математичних уявлень важливо, можливо і доцільно використовувати алгоритмічний підхід під час вивчення окремих тем курсу. При цьому використання алгоритмів можливе через формулювання їх викладачем чи самостійне виокремлення кроків алгоритму студентами.

Значення такої роботи на заняттях важко переоцінити. Використання алгоритмічного підходу дає можливість студентам логічно будувати схеми навчання дітей, закріпити знання послідовності проведення тієї чи тієї роботи, формує глибину професійних знань і вмінь, розвиває логічне, критичне мислення та інтерес до предмета, допомагає виявляти недоліки у викладанні.

Важливо дати можливість студентам після прослуханої лекції скласти алгоритм підготовки вихователя до заняття; він може бути таким:

1. Визначити тему, мету заняття та програмові вимоги до вивчення матеріалу дошкільниками.

2. Дібрати дидактичні засоби до теми.

3. Обрати методи навчання дошкільників.

3. Спланувати різні форми організації навчальної діяльності на занятті.

4. Використати різні форми спілкування з дітьми, врахувавши цілі заняття.

5. Спроектувати характер взаємодії дітей на занятті.

6. Спланувати результативність заняття.

7. Написати план-конспект заняття.

Цікавою особливістю окремих алгоритмів $€$ їх неодноразова застосовність вихователем. Отже, склавши типовий алгоритм, студенти можуть 3 упевненістю їх використовувати згідно з чинною програмою в різних вікових групах.

Для прикладу наведемо алгоритм засвоєння числа і цифри (наприклад, 3):

1. Розглянути вправу на утворення числа (3).

2. Опрацювати завдання на співвіднесення числа та кількості предметів і навпаки.

3. Розглянути запис числа цифрою.

4. Виконати вправи на запам'ятовування вигляду цифри:

a) виявити схожість з предметами, тваринами (два гачки, два банани, вигнутий шарф, півсніговика, крила птаха тощо);

б) обвести пальчиком по контуру цифри (можна використати «цифри-шершавчики»);

в) викласти зі смужок, природного матеріалу, заштрихувати;

г) написати у повітрі, на піску, по снігу тощо.

5. Порівняти число з раніше вивченими (2 та 1).

6. Опрацювати числа-сусіди (2 і 4).

7. Розглянути кількісний склад числа з одиниць та двох менших чисел.

8. Розв'язати задачі в межах цього числа.

Для перевірки знань студентів можна запропонувати картку 3 неправильною 
послідовністю операцій і запропонувати розмістити їх у правильній послідовності.

Алгоритм «Ознайомлення дітей 3 новою геометричною фігурою» можна запропонувати скласти окремим студентам (під час індивідуальної чи групової роботи на занятті або самостійної роботи вдома). Цей алгоритм може бути таким:

1. Показати (продемонструвати) геометричну фігуру і назвати іiі.

2. Обстежити геометричну фігуру дотиково-зоровим способом (обведення по контуру, ознайомлення з особливостями фігури).

3. Розглянути геометричні фігури, різні за кольором і розміром.

4. Порівняти геометричну фігуру з предметами, близькими за формою.

5. Порівняти геометричну фігуру з іншими геометричними фігурами. Знайти фігуру серед інших.

6. Засвоїти властивості геометричної фігури під час малювання, ліплення, аплікації.

Досвід роботи доводить, що такі алгоритми можна складати з будь-якої теми методики формування елементарних математичних уявлень. Автоматизація складання алгоритмів дає можливість студенту і вихователю бачити заняття в сукупності як єдине ціле, приділяти увагу розвитку розумової діяльності дітей, планувати індивідуальну роботу на занятті, використовувати різноманітні наочні посібники на заняттях і в повсякденній діяльності. Оволодіння алгоритмами дозволяє вихователю бачити окремі елементи в розв'язанні будь-якого завдання, глибоко аналізувати свою роботу і роботу колег, брати активну участь у творчому процесі навчання дітей, формувати свої професійні навички.

Особливе місце в логіко-математичній підготовці дошкільників займають задачі. Навчання розв'язувати задачі в дошкільному навчальному закладі і навіть у школі є чи не найважчим. Щоб воно було успішним, вихователь повинен від найпершої задачі проводити правильну методичну роботу: розвивати уяву дітей, диференціювати роботу над задачами, правильно проводити розбір задачі.

Задля цього задачу опрацьовуємо за таким алгоритмом:

1. Прочитати задачу і переконатися, що діти розуміють її сюжет.

2. Виділити числові дані задачі.

3. Повторити, що означає кожне число і що треба знайти.

4. Провести роботу з предметними множинами чи іншим унаочненням задачі.

5. Вибрати арифметичну дію.

6. Скласти приклад до задачі.

7. Обчислити з дітьми розв'язок задачі.

Алгоритмізація навчання передбачає єдність між аналізом і синтезом i активно впливає на творче мислення студентів. Як зазначає академік Б. Гнеденко, «як би далеко не просунулися досягнення педагогіки у розв'язанні завдання розвитку творчих здібностей і логічного мислення людей, у ній завжди будуть займати почесне місце алгоритмічні методи» [2, с. 20].

У широкому розумінні проблема алгоритмізації навчання студентів - це організація мислення особистості, тобто використання алгоритмів у стандартних репродуктивних ситуаціях задля створення фундаменту для розвитку творчого потенціалу особистості. На перший погляд, алгоритмічні навички - це лише точне виконання певної інструкції, адже результат формування алгоритмічного стилю мислення забезпечує лаконічність, точність i впорядкованість мисленнєвих операцій. За твердженням Норберта Вінера, ніщо так не звільняє мозок для творчості, як добре знання алгоритмів.

Досліджуючи окремі аспекти проблеми використання алгоритмів у процесі навчання, 
С. Шапіро вказує на те, що:

- застосування приписів алгоритмічного типу сприяє ефективному засвоєнню й оцінюванню набутих знань, надає можливість ураховувати індивідуальні особливості учнів;

- алгоритмічні приписи як засоби управління об'єктами перетворюються в засоби управління мисленням;

- формування методів мислення - це спосіб виховання розумових здібностей учнів;

- розв'язування завдань за допомогою приписів - одна 3 умов розвитку інтуїції [5, с. 46].

Питання алгоритмічного i творчого мислення (пошук розв'язків завдань у нестандартних ситуаціях, використання методу спроб і помилок) постійно дискутується в науковій літературі.

Отже, ми вважаємо, що алгоритмічний підхід важливо, можливо і доцільно використовувати у процесі методично-математичної підготовки студентів- майбутніх вихователів дошкільних навчальних закладів. Часткова алгоритмізація навчального процесу (де вона є доцільною) сприяє його вдосконаленню, ефективному та свідомому формування професійних навичок студентів, їх розумовому розвитку.

Застосовуючи алгоритмічний підхід у навчанні, викладач має можливість показати студентам готові зразки дій, формує уміння і навички професійної діяльності, навчає студентів бачити послідовність у роботі, складники практичної діяльності вихователя. Алгоритмічний підхід у поєднанні з іншими методами навчання у вищій школі (проблемне, інтерактивне навчання, метод проектів тощо) підвищує осмисленість засвоєння, полегшує і прискорює вивчення програмного матеріалу.

Набуті навички є необхідним компонентом творчого процесу, без них він просто неможливий. Адже навчання студентів передбачає запам'ятовування, використання засвоєних алгоритмів на практиці, а також їх самостійне «відкриття», побудову та втілення, а це $є$ творчим процесом. Отже, алгоритмізація може бути ефективним засобом навчання творчого мислення. Використання алгоритмів сприяє також тому, що розумова діяльність студентів упорядковується i систематизується, створюючи основу для професійного зростання, сприяючи інтелектуальному розвитку майбутніх фахівців дошкільної освіти.

\section{Література}

1. Беспалько В. П. Слагаемые педагогической технологии / В. П. Беспалько. Москва : Педагогика, 1989. - 223 с. 2. Гнеденко Б. В. О математическом творчестве / Б. В. Гнеденко // Математика в школе. - 1979. - №6. - С. 16-22. 3. Закон України «Про освіту» / [Електронний ресурс]. - Режим доступу : http://zakon4.rada.gov.ua/ laws/show/106012 4. Ланда Л. Н. Алгоритмизация в обучении / Л. Н. Ланда. - Москва : Просвещение, 1966. - 523 с. 5. Шапиро С. И. От алгоритмов к суждениям (эксперименты по обучению элементам математического мышления)/ С.И.Шапиро.- Москва : Советское радио, 1973. $-288 \mathrm{c}$. 